\title{
Strategi Menulis Karya Ilmiah Model Pembelajaran Kolaboratif Berbasis Problem Based Learning pada Mahasiswa Administrasi Bisnis Politeknik Informatika Nasional
}

\author{
Husni Bt. Salam \\ Program Studi Administrasi Bisnis, Politeknik Informatika Nasional LP3I \\ Makassar \\ uniesalam53@gmail.com
}

\begin{abstract}
Abstrak
Penelitian ini bertujuan untuk meningkatkan kemampuan mahasiswa Admnistrasi Bisnis dalam menyusun karya ilmiah. Penelitian ini yakni penelitian deskriptif kualitatif yang berorientasi pada pendeskripsian kemampuan mahasiswa dalam menulis karya ilmiah Model Pembelajaran Kolaboratif Berbasis Problem Learning. Desain penelitian yang digunakan adalah penelitian tindakan kelas (PTK) menggunakan desain PTK Kemmis dan Taggart. Metode pengumpulan data adalah metode observasi dan metode intropeksi. Teknik pengumpulan data yaitu teknik wawancara, teknis tes pemberian soal dan dokumentasi. Teknik analisis data yang digunakan yakni melakukan empat kali pertemuan setiap siklusnya kemudian menganalisis setiap hasil siklus yang didapatkan. Hasil penelitian ini menunjukkan pendekatan metode kolaboratif dan $P B L$ dalam menulis dan menyusun karya ilmiah dapat meningkatkan pengetahuan mahasiswa Administasi Bisnis. Peningkatan kemampuan dan pemahaman mahasiswa dapat dilihat pada keaktifan dan keantusiasan mahasiswa dalam melakukan kolaboratif. Peningkatan dari segi kualitas tercermin dari produk hasil menulis karya ilmiah pada siklus I, dan II, . Pada siklus I nilai rata-rata 12 dengan persentase 61\% untuk aspek bagian awal, 74\% untuk aspek bagian isi, 63\% bagian notasi ilmiah dan $61 \%$ untuk mekanisme penulisan. Pada siklus ke 2 rata-rata nilai yang diperoleh mahasiswa sebesar 16 dengan persentase 77\% untuk aspek bagian awal, 80\% untuk aspek bagian isi, $85 \%$ bagian notasi ilmiah dan $77 \%$ untuk mekanisme penulisan.
\end{abstract}

Kata kunci: Kolaboratif; Problem Based Learning

\begin{abstract}
This study aims to improve the ability of Business Administration students in compiling scientific papers. This research is a qualitative descriptive study that is oriented towards describing the ability of students in writing scientific papers on Problem Learning Based Collaborative Learning Models. The research design used was classroom action research (PTK) using the design of PTK Kemmis and Taggart. The data collection methods are observation and introspection methods. The data collection techniques were interview techniques, question-giving test techniques and documentation. The data analysis technique used was to conduct four meetings per cycle then analyze each cycle result obtained. The results of this study indicate that the collaborative method approach and PBL in writing and compiling scientific papers can increase the knowledge of Business Administration students. Increased ability and understanding of students can be seen in the activeness and enthusiasm of students in collaborating. The improvement in terms of quality is reflected in the products written by scientific papers in cycles I, and II ,. In the first cycle, the average value was 12 with a percentage of 61\% for the initial aspect, 74\% for the content aspect, 63\% for the scientific notation section and 61\% for the writing mechanism. In the second cycle the average score obtained by students was 16 with a percentage of 77\% for the initial aspect, 80\% for the content aspect, 85\% for the scientific notation section and 77\% for the writing mechanism.
\end{abstract}

Keywords: Colaborative; Problem Based Learning

Halaman| 693 


\section{Pendahuluan}

Pembelajaran menulis karya ilmiah merupakan salah satu indikator penting bagi setiap mahasiswa. Pengguna bahasa yang baik dalam hal ini mahasiswa sangat diharapkan mempunyai pemahaman dalam karya ilmiah. Diketahui bersama bahwa ada beberapa alasan mengapa menulis karya ilmiah memiliki kontribusi penting karena kegiatan menulis merupakan suatu media bagi seseorang dalam menemukan sesuatu objek, sehingga seseorang mampu melatih minda yang dimilikinya untuk lebih terasah khususnya bagi mahasiswa. Kemampuan menulis setiap mahasiswa tidak didapatkan begitu saja atau diwarisi dari para kerabatnya, namun setiap mahasiswa perlu diasah dan dipelajari secara sunguh-sungguh mulai pendidikan sekolah sebagai bahan pengetahuan di perguruan tinggi. Oleh karena itu, dibutuhkan peran penting pengajar untuk menemukan model pembelajaran menulis karya ilmiah agar mahasiswa mendapat pemahaman yang lebih mendalam tentang karya ilmiah. Menurut Nurgiyantoro dalam (Musaljon et al., 2019) tugas menulis defenisi sesungguhnya, adalah menulis untuk melahirkan karya tulis. Sehubungan dengan kegiatan menulis makalah ilmiah, tugas menulis seharusnya tidak hanya semata-mata memproduksi bahasa saja, melainkan bagaimana menyalurkan ide sebagai alat bahasa tulis yang sesuai juga memperhitungkan bentuk, jenis, dan variasi tulisan. Salah satu variasi tulisan ilmiah, diantaranya makalah ilmiah, indikator penilaiannya meliputi isi pendapat yang dikemukakan, struktur isi, gramatikal, diksi serta ejaan dan penggunaan tanda baca.

Karya ilmiah merupakan catatan yang mengandung informasi sebagai hasl penelitain maupun hasil pemikiran penulisnya yang dipublikasikan melalui media tertentu. Penulisan karya ilmiah hal yang penting untuk mahasiswa. Hal ini seperti yang dipaparkan oleh (Nasucha, 2017) bahwa mahasiswa melakukann kegiatan atau penerapan pemahaman keterampilan menulis dalam seluruh metode kegiatan pelaksanaan pembelajaran di perguruan tinggi. Di awal semester mahasiswa diwajibkan menulis makalah untuk setiap mata kuliah yang mereka dapatkan. Tujuan dari pemberian tugas tersebut sebagai wujud pengenalan untuk mahasiswa dalam menulis makalah. Indikator penulisan karya ilmiah nantinya sebagai proses pembelajaran mereka dalam menulis skripsi, tesis, atau disertasi yang didahului dengan penulisan proposal penelitian yang akan mereka jalani pada saat berada di semester akhir.

Perkuliahan yang merujuk pada pengembangan kemampuan menulis di perguruan tinggi di Indonesia pada program studi nonkebahasaan pada dasarnya hanya merupakan sebagian kecil dari ruang lingkup mata kuliah Bahasa Indonesia. Keadaan ini tampak bertolak belakang dengan tuntutan kemampuan menulis karangan ilmiah yang diharapkan dapat dilakukan mahasiswa. Pada kenyataannya para mahasiswa mengalami kesukaran dalam menulis karangan ilmiah jenis makalah yang ditugaskan oleh dosen. Para mahasiswa kebanyakkan membuat makalah yang tidak sesuai dengan penulisan karya ilmiah. Salah satu faktor yakni kurangnya pemahaman dalam menulis karangan ilmiah yang dimiliki oleh setiap mahasiswa (Kusmana et al., 2019).

Dari pengamatan penulis, mahasiswa di Politeknik Informatika Nasional masih belum mampu membuat karya tulis ilmiah dengan level penguasaan menulis yang baik Beberapa faktor yang menyebabkan kurangnya pengetahuan mahasiswa di POLINAS dalam menulis karya ilmiah adalah kurangnya minat mahasiswa dalam membaca sehingga minimnya pengetahuan pembendaharaan kata yang mereka miliki. Efek dari 
kurangnya perbendaharaan kata ini sangat memengaruhi ketika mahasiswa akan menuangkan ide dalam bentuk narasi yang akan di tulis. Selain itu juga, kurangnya motivasi mahasiswa dalam proses pembelajaran sehingga materi yang diberikan kepada mahasiswa tidak terserap dengan sempurna khususnya dalam pembelajaran bahasa Indonesia yang banyak disepelekan oleh mahasiswa misalnya penggunaan tanda baca, penulisan huruf kapital, penulisan huruf miring stuktur kata yang benar dan sebagainya.

Metode kolaboratif berbasis Problem Based Learning dianggap sesuai sebagai sarana yang mampu meningkatkan pengetahuan mahasiswa dalam menulis karya tulis ilmiah. Istilah Pembelajaran Berbasis Masalah (PBM) dikutip dari istilah Inggris yaitu Problem Based Instruction (PBI). Model pembelajaran ini mulai dilaksanakan karena secara umum pembelajaran ini diawali dengan menyajikan situasi masalah nyata dan bermakna kepada siswa sehingga siswa mampu melakukan proses penelitian dan inkuiri dengan mudah. Masalah yang diberikan pada saat pembelajaran digunakan sebagai landasan proses bentuk pembelajaran (Tanjung \& Nababan, 2018).

Problem Based Learning merupakan pengajaran proses berfikir tingkat tinggi. Pembelajaran ini membantu mahasiswa untuk memproses keterangan yang sudah siap yang dimiliki mindanya dan menyusun pengetahuan mereka sendiri tentang dunia sosial dan apa yang ada di sekelilingnya. Pembelajaran ini bermanfaat untuk meluaskan pengetahuan yang dangkal maupun yang bersifat rumit.

Berdasarkan beberapa pemaparan, maka penulis tertarik meneliti Strategi Menulis Karya Tulis Ilmiah Model Pembelajaran Kolaboratif Berbasis Problem Learning pada Mahasiswa Program Studi Admnistrasi Bisnis di Politeknik Informatika Nasiona Makassar.

\section{Kerangka Teori}

Menurut Wina dalam (Suryani \& Agung, 2012) strategi pembelajaran adalah suatu aktivitas belajar mengajar yang wajib dilakukan guru dan siswa agar sasaran pembelajaran dapat ditarget secara efektif dan efisien.

Menurut Fatimah \& Kartikasari (2018) strategi yang terkonsep mempunyai peranan penting dalam proses pembelajaran. Strategi erat kaitannya dengan teknis dalam melakukan pembelajaran tersebut. Agar metode tersebut tidak jauh dari target yang ingin dicapai, perlu pemahaman yang lebih. Pemahaman tersebut diawali dari rangsangan pada setiap individu dalam upaya mendorong dan memotivasi sehingga memberikan feedback dalam aktivitas pembelajaran bahasa. Dari beberapa pendapat di atas diperoleh sebuah simpulan bahwa strategi pembelajaran adalah rangkaian kegiatan yang teratur, pola-pola umum aktivitas guru yang berhubungan tentang urutan kegiatan pembelajaran, untuk mencapai maksud yang telah ditentukan. Hal ini mencakup:(1) urutan kegiatan pembelajaran, (2) metode pembelajaran, (3) media pembelajaran, dan (4) waktu yang digunakan oleh guru dalam menyelesaikan setiap langkah kegiatan pembelajaran.

Kolaborasi merupakan pengembangan diri untuk setiap orang dengan cara mengembangkan potensi dan kesenangan yang dimiliki oleh setiap individu. Beberapa bentuk kolaborasi yang dilakukan oleh siswa atau mahasiswa yakni menulis puisi, fiksi, atau artikel opini. Segala bentuk kerja keras yang dilakukan oleh mereka akan menunjukkan keberhasilan dalam menulis sesuatu yang berhubungan dengan karangan. Kolaborasi merupakan teknik belajar menulis dengan melibatkan sejawat untuk saling mengoreksi. Sejawat yang diajak berkolaborasi itu di sebut kolaborator 
dan juga kolaborasi adalah tempat bertegur sapa dan bersilaturahmi ilmu pengetahuan. Di situ ada pembelajaran yang dilakukan secara bersama-sama atau lebih akrab disebut dengan berjamaah (social learning). Prinsip dalam social learning memberikan konsep bahwa tiap orang memiliki kelebihan tersendiri sehingga tidak ada orang yang tidak mempunyai kelebihan. (Sriyanti, 2017).

Biasanya dalam perihal belajar mengajar untuk melatih dan memberdayakan mahasiswa metode kolaboratif digunakan sebagai solusi yang tepat. Pada kelas yang cukup padat, akan dibuatkan menjadi beberapa grup kecil untuk melakukan kolaborasi. Dalam setiap grup, siswa membaca hasil tulisan yang dibuat oleh teman sejawatnya lalu dikoreksi. Kolaborasi ini bukan tempat untuk melihat kesalahankesalahan orang lain, namun sebagai ajang intropeksi bersama, agar mampu menyelesaikan suatu permasalahan dan memperbaiki suatu kesalahan.

Pengajaran melalui masalah diketahui sejak era John Dewey. Menurut Dewey (Trianto, 2011) belajar melalui masalah yaitu korelasi antara rangsangan dan respon, adalah kaitan antara belajar dan kondisi keadaaan sekeliling. Suatu keadaan melahirkan pengarahan kepada mahasiswa berupa pertolongan dan masalah, di samping itu struktur saraf otak berguna mengindentifikasi pertolongan itu itu secara efesien sehingga problem yang ditemukan dapat diteliti, diukur, dianalisis, serta diberikan solusi yang lebih apik dan bermanfaat. Pembelajaran Berbasis Masalah yang merupakan asal muasal dari bahasa Indonesia. Problem-based Learning yakni suatu ide pembelajaran yang dimulai dengan menyelesaikan suatu permasalahan, namun untuk menuntaskan suatu masalah itu siswa membutuhkan pengetahuan baru untuk mengahsilkan dan menemukan titik suatu permasalahan. Pendekatan pembelajaran berbasis masalah (problem-based learning/PBL) adalah ide pembelajaran yang membantu mahasiswa menghasilkan kondisi lingkungan pembelajaran yang didahului dengan masalah dan relevan bagi setiap mahasiswa, dan memberikan peluang mahasiswa memeroleh pengetahuan belajar yang lebih nyata. Menurut Wulandari \& Surjono (2013) PBL adalah lingkungan atau kondisi belajar yang di dalanya menggunakan masalah untuk belajar. Sebelum pembelajar mempelajari suatu hal yang belum mereka ketahui maka, mereka diwajibkan mengenali suatu masalah, baik yang dihadapi secara nyata maupun telaah suatu kasus. Masalah diberikan sebagai bahan acuan bagi pembelajar pembelajar menemukan dan mensiasati segala kebutuhan belajar yang yang harus mereka miliki agar dapat memecahkan masalah tersebut.

\section{Metode Penelitian Jenis Penelitian}

Penelitian ini adalah penelitian deskriptif kualitatif yakni penelitian yang berorientasi pada kemampuan mahasiswa dalam menulis karya tulis ilmiah.

\section{Lokasi Penelitian}

Penelitian ini akan diadakan di Makassar dengan pengambilan di Politeknik Informatika Nasional sebagai lokasi penelitian.

\section{Populasi dan sampel}

Populasi dalam penelitian ini adalah keseluruhan mahasiswa Politeknik Informatika Nasional. Sampel dalam penelitian ini adalah mahasiswa program studi Admnistrasi Bisnis. 
Volume 6 Nomor 2

\section{Prosedur Penelitian}

Prosedur yang di tempuh dalam penelitian ini terdiri atas empat tahapan yaitu:

1. Tahap Persiapan

Sebelum melaksanakan pembelajaran terlebih dahulu dilakukan persiapan diantaranya:

a. Mengembangkan perangkat pembelajaran

b. Mengembangkan instrumen penelitian; lembar observasi aktivitas siswa, angket respons siswa, tes hasil belajar.

2 Tahap pelaksanaan.

3. Menerapkan berbasis Collaborative dan Problem Based Learning selama 3 bulan

4. Tahap evaluasi

Pada akhir materi pelajaran, dilakukan tes hasil belajar kognitif, afektif dan psikomotorik untuk mengukur kemampuan pemahaman konsep, prinsip, dan keterampilan mahasiswa dalam menulis karya ilmiah.

\section{Teknik pengumpulan data}

Observasi

Observasi dilakukan untuk mengumpulkan data dan informasi yang berhubungan dengan kondisi kampus seperti jumlah kelas, jumlah mahasiswa dan proses pembelajaran.

\section{Dokumentasi}

Penerapan teknik dokumentasi dilakukan dengan cara mengumpulkan datadata dalam bentuk dokumentasi sesuai dengan objek penelitian, seperti foto-foto pada saat proses pembelajaran dan video.

\section{Teknik Analisis Data}

Adapun langkah dalam pengolahan data yakni sebagai berikut:

1. Analisis data hasil pemantauan terhadap kegiatan tindakan pada setiap siklus melalui teknik analisis dekripstif kualitatif.

2. Menentukan rata-rata nilai mahasiswa mengikuti tes yakni:

a. Penskoran terhadap hasil penyusunan karya ilmiah mahasiswa

b. Tingkat keberhasilan mahasiswa dalam menyusun karya ilmiah dengan metode kolaboratif dan PBL dengan menggunakan rumus:

$$
\text { Nilai Akhir }(N A)=\frac{\text { Perolehan Skor Siswa }}{\text { Skor Maksimum }} 100
$$

Selanjutnya dihitung nilai rata-rata siswa setiap siklus (Sudjana, 2017)

$$
\text { Nilai rata }- \text { rata }(X)=\frac{\text { Jumlah Skor Keseluruhan }}{\text { Jumlah Siswa }}
$$

3. Selanjutnya untuk mengetahui persentase ketuntasan siswa maka digunakan rumus:

$$
\text { Ketuntasan Kelas }=\frac{\Sigma \text { Jumlah siswa yang tuntas }}{\text { Jumlah Siswa }}
$$

4. Penarikan simpulan 


\section{Hasil dan Pembahasan}

Pemberian tes awal yakni sebuah pratindakan untuk mngetahui sejauh mana kemampuan mahasiswa Administrasi Bisnis dalam menyusun karya ilmiah khususnya makalah. Tes awal (Pratindakan) diberikan kepada 25 mahasiswa. Kemudian dilanjutkan dengan pelaksanaan siklus 1 .

Hasil pratindakan memperlihatkan kemampuan mahasiswa kelas AB Polinas Makassar melalui menulis karya ilmiah masih kurang. Indikator yang dinilai dalam penilaian menyusun karya ilmiah mahasiswa yakni bagaimana mahasiswa menentukan pada bagian awal karya ilmiah, bagian isi, aspek notasi dan mekanisme penulisan karya ilmiah. Setiap aspek yang diberikan memiliki memiliki nilai 5 untuk nilai tertinggi. Adapun nilai keseluruhan yang ideal dalam praktik menulis karya ilmiah adalah 20.

Pada siklus 1 peneliti melakukan empat tahapan seperti yang dipaparkan oleh Kemmis dan Mc-Taggart, yakni melalui proses (1) Perencanaan, (2)Pelaksanaan, (3) Pengamatan, dan (4) Refleksi.

Adapun hasil pratindakan dan siklus 1 dapat dilihat pada grafik dan tabel di bawah ini:

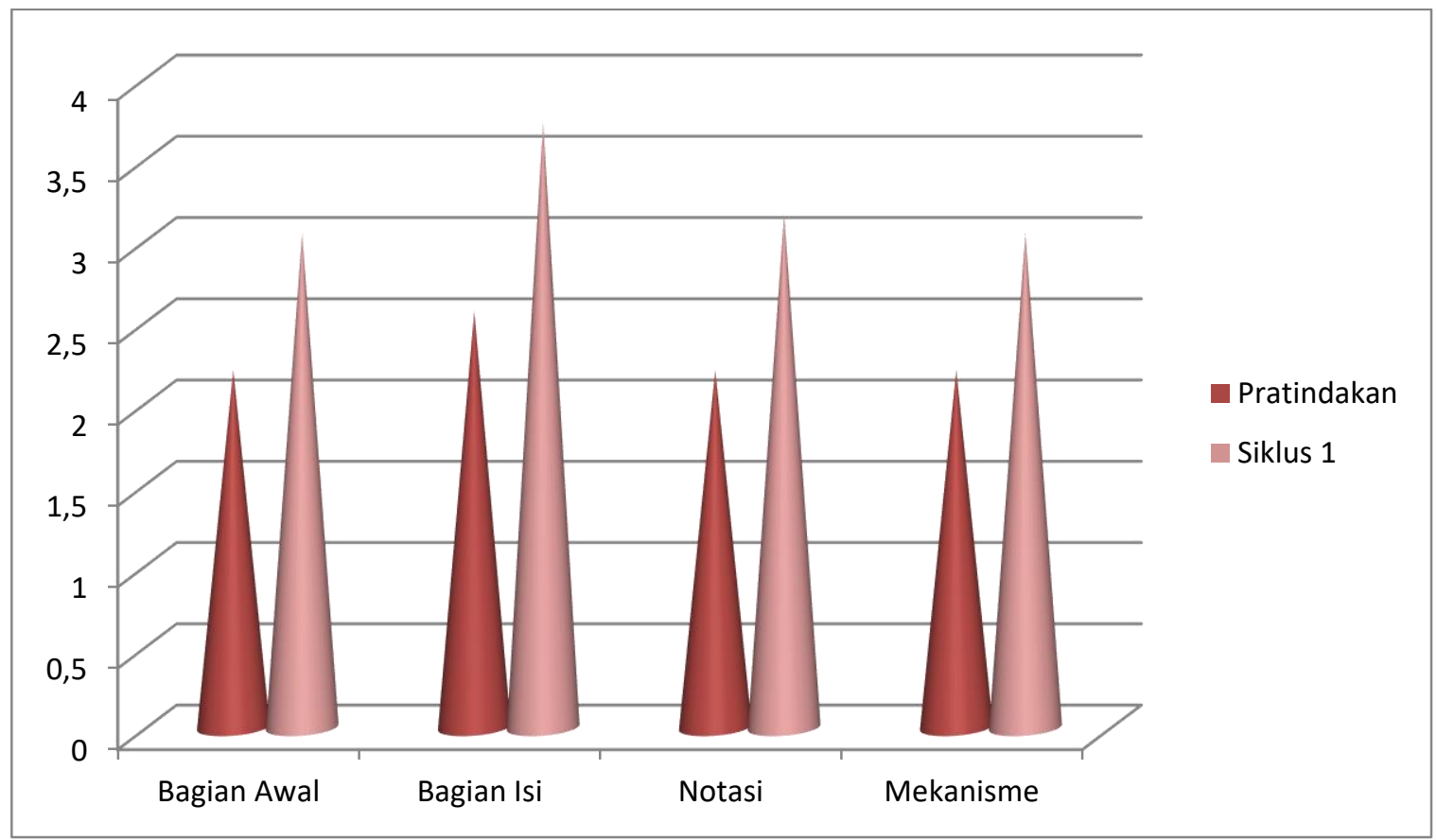

Grafik 1: Nilai Rata-Rata Pratindakan dan Siklus 1

Tabel 1. Nilai Rata-Rata Pratindakan dan Siklus 1

\begin{tabular}{|c|l|l|l|l|}
\hline No & Unsur & $\begin{array}{l}\text { Nilai } \\
\text { Pratindakan }\end{array}$ & $\begin{array}{l}\text { Nilai } \\
\text { Siklus I }\end{array}$ & Peningkatan \\
\hline 1 & Bagian awal & 2,20 & 3,04 & 0,84 \\
\hline 2 & Bagian isi & 2,56 & 3,72 & 1.16 \\
\hline 3 & $\begin{array}{l}\text { Notasi } \\
\text { ilmiah }\end{array}$ & 2,20 & 3.16 & 0.96 \\
\hline 4 & $\begin{array}{l}\text { Mekanisme } \\
\text { penulisan }\end{array}$ & 2,20 & 3.04 & 0.84 \\
\hline
\end{tabular}


Hasil grafik dan tabel di atas menujukkan bahwa adanya peningkatan pemahaman mahasiswa dalam menyusun karya ilmiah pada siklus 1 dibandingkan pada saat pratindakan. Ini terlihat pada nilai rata-rata mahasiswa pada pratindakan dan siklus I sebagai berikut 1) Bagian awal sebesar 0.84, aspek (2) Bagian isi sebesar 1.16 aspek (3) notasi ilmiah sebesar 0.96, aspek (4) mekanisme penulisan sebesar 0.84 . Walaupun dari hasil grafik belum menunjukkan hasil yang signifikan namun pada siklus 1 dengan menerapkan metode kolaboratif dan Problem Based Learning mampu meningkatkan pemahaman mahasiswa dalam menyusun makalah.

Adapun hasil pratindakan dan siklus II dapat dilihat pada grafik dan tabel di bawah ini:

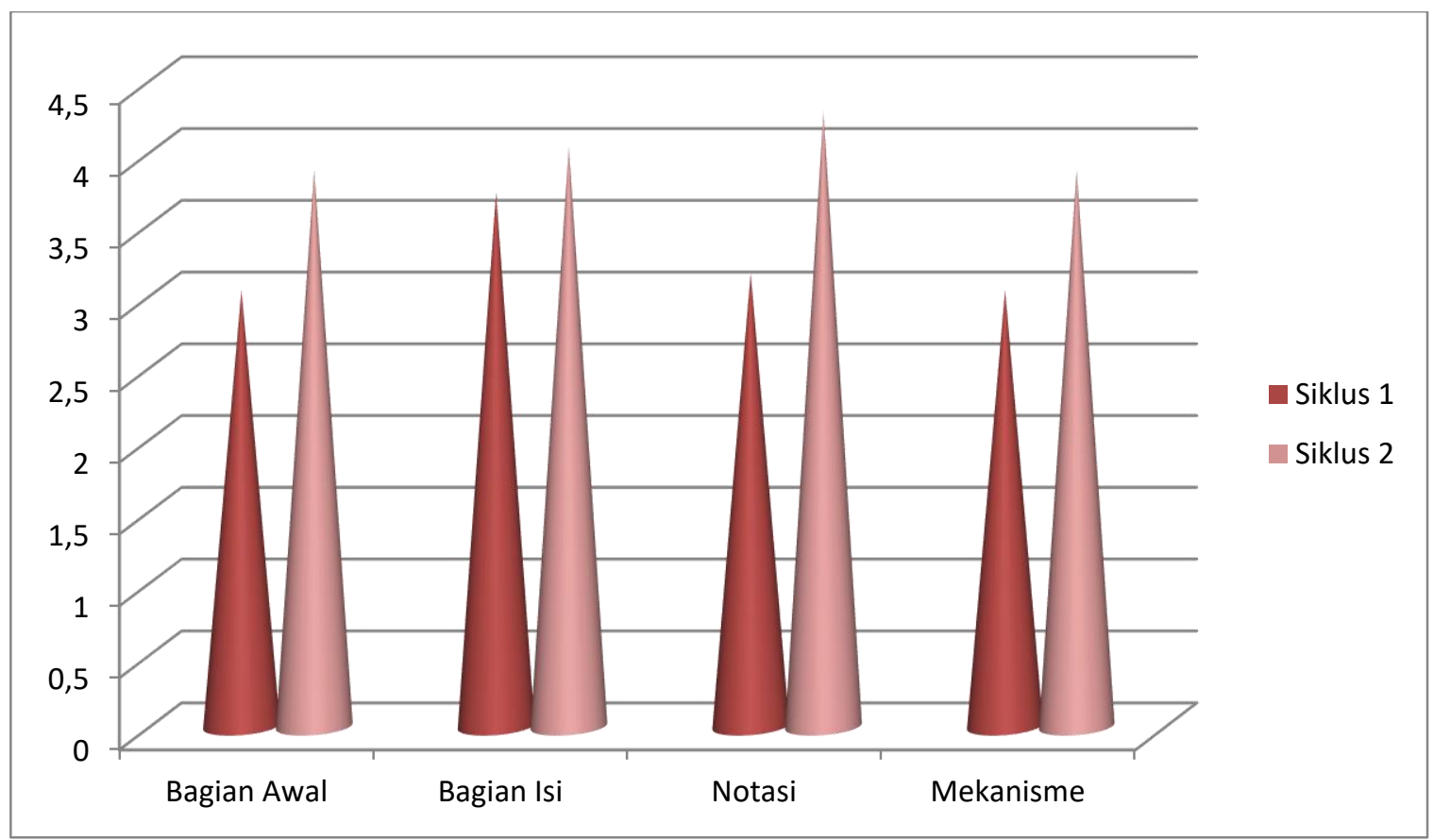

Grafik 1: Nilai Pratindakan dan Siklus 1

Tabel 2: Nilai Membuat Karya Ilmiah Siklus 1 dan Siklus II

\begin{tabular}{|l|l|l|l|l|}
\hline No & Unsur & $\begin{array}{l}\text { Nilai Rata-Rata } \\
\text { Siklus I }\end{array}$ & $\begin{array}{l}\text { Nilai Rata-Rata } \\
\text { Siklus II }\end{array}$ & Peningkatan \\
\hline 1 & Bagian awal & 3.04 & 3.88 & 0.84 \\
\hline 2 & Bagian isi & 3,72 & 4.04 & 0.32 \\
\hline 3 & Notasi ilmiah & 3.16 & 4.28 & 1.12 \\
\hline 4 & $\begin{array}{l}\text { Mekanisme } \\
\text { penulisan }\end{array}$ & 3.04 & 3.88 & 0.84 \\
\hline
\end{tabular}

Berdasarkan tabel dan grafik di atas dapat disimpulkan bahwa kemampuan mahasiswa dalam menyusun karya ilmiah mengalami peningkatan pada setiap aspek penilaian aspek karya ilmiah yaitu dapat dilihat dalam perbandingan antara nilai ratarata kelas pada siklus I dan siklus II sebagai berikut 1) Bagian awal sebesar 0.84, aspek (2) Bagian isi sebesar 0.32, aspek (3) notasi ilmiah sebesar 1.12, dan aspek (4) mekanisme penulisan sebesar 0.84 .

Hasil penelitian yang dilakukan pada siklus II yakni adanya peningkatan 
kemampuan mahasiswa menulis makalah. Berdasarkan hasil pengamatan dan uji kompetensi yang dilakukan peneliti pada tindakan siklus II, dapat dikatakan bahwa pembelajaran sudah tampak adanya peningkatan, karena mahasiswa sudah mulai memahami materi pelajaran yang diberikan. Dosen tidak mengalami kesulitan dalam memberikan bimbingan, karena dosen dan mahasiswa sudah mulai memahami tentang metode pembelajaran yang digunakan dalam membuat karya ilmiah. Keefektifan dalam menggunakan metode dalam sebuah pengajaran sangat memengaruhi hasil pemahaman mahasiswa karena metode yang digunakan tidak bersifat konvensional seperti pemberian mata kuliah lainnya sehingga memudahkan mahasiswa mempelajari suatu permasalahan yang diberikan.

Hasil nilai secara keseluruhan mahasiswa dalam menyusun karya ilmiah dapat dilihat pada grafik di bawah ini:

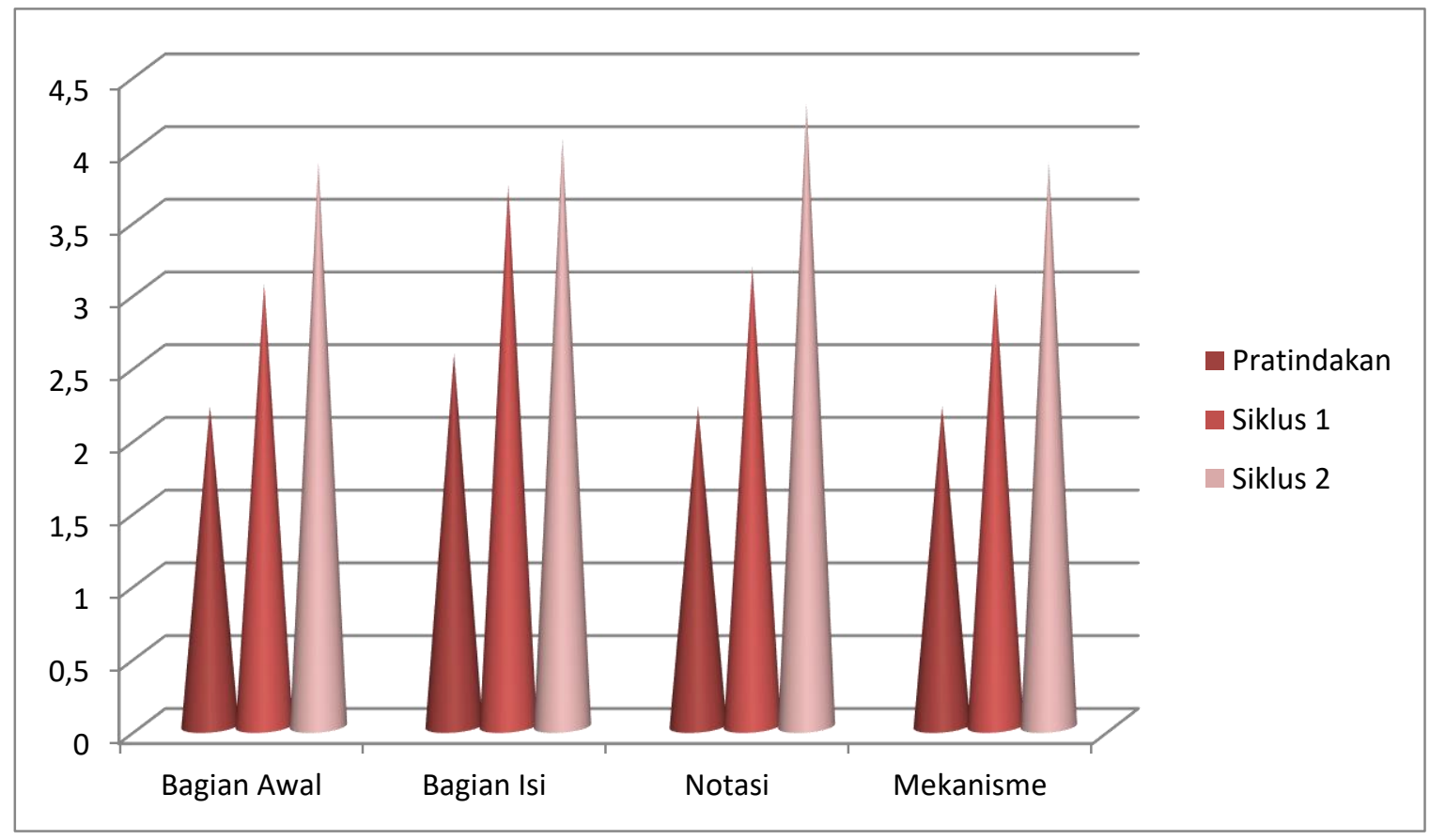

\section{Grafik 1: Nilai Pratindakan Siklus I, dan II}

Grafik di atas menunjukkan bahwa peningkatan pemahaman mahasiswa dalam menyusun karya ilmiah pada pratindakan siklus 1, dan 2. Pada pratindakan rata-rata mahasiswa memperoleh nilai rata-rata 9 dari nilai maksimal 20 dengan persentase 44\% untuk aspek bagian awal, 51\% untuk aspek bagian isi, 44\% untuk aspek notasi dan 44\% untuk aspek mekanisme penulisan. Setelah diberikan metode kolaboratif dan problem based learning pada siklus 1 , terjadi peningkatan yakni memeroleh nilai ratarata 12 dengan persentase $61 \%$ untuk aspek bagian awal, 74\% untuk aspek bagian isi, $63 \%$ bagian notasi ilmiah dan 61\% untuk mekanisme penulisan . Pada siklus ke 2 ratarata nilai yang diperoleh mahasiswa sebesar 16 dengan persentase $77 \%$ untuk aspek bagian awal, $80 \%$ untuk aspek bagian isi, $85 \%$ bagian notasi ilmiah dan $77 \%$ untuk mekanisme penulisan. Ini terlihat pada aspek bagian isi yang hampir memeroleh nilai 4 dan bagian notasi memeroleh nilai 4 setiap mahasiswa. Berdasarkan dari 2 siklus yang dilaksanakan menggunakan metode kolaboratif dan PBL bahwa dengan menggunakan mentode ini mahasiswa Administrasi Bisnis Politeknik Informatika mampu menyusun dan menulis makalah dengan baik. 
Peningkatan pembelajaran tampak pada peningkatan keantusiasan dan keaktifan mahasiswa dalam proses pembelajaran yang mengutamakan strategi kolaboratif dan pemecahan masalah. Strategi yang digunakan sebagai landasan dalam menulis atau menyusun karya ilmiah. Strategi atau metode kolaboratif merupakan metode yang dianggap penting sehingga mampu membuat mahasiswa lebih mengeksplor pola pikir yang mereka miliki. Dalam menyusun karya ilmiah pemecahan masalah sangat dibutuhkan agar memudahkan mahasiswa dalam menyusun suatu karya ilmiah. Adapun pemecahan masalah yang diberikan kepada mahasiswa bersumber dari hal-hal yang berada disekeliling mereka dan masalah nyata yang ada dikehidupan sehari-hari sehingga mahasiswa berusaha untuk memecahkan suatu permasalahan. Maka dari itu, keantusiasan dan keaktifan mahasiswa sangat jelas terlihat seperti aktif mendiskusikan suatu permasalahan yang belum terpecahkan dalam melakukan kolaboratif bersama teman kelompok agar mereka mampu memecahkan uatu permasalahan dalam hal ini menyusun karya ilmiah.

Selain itu, wujud peningkatan pengetahuan menulis karya ilmiah mahasiswa Administrasi Bisnis melalui penerapan strategi kolaboratif dan problem based learning berfokus pada empat aspek dalam menulis karya ilmiah yakni bagian awal, bagian isi, notasi ilmiah dan mekanisme penulisan karya ilmiah. Empat aspek ini merupakan hal mendasar dalam menulis dan menyusun karya ilmiah khususnya makalah sebagai langkah awal untuk memudahkan dalam menyusun tugas akhir pada mahasiswa semester akhir.

Prosedur kolaboratif dan problem based learning mencakup (1) mahasiswa dibagi menjadi beberapa kelompok (2) mahasiswa berkolaboratif secara sinergi mengidentifikasi permasalahan yang diberikan, (3) mahasiswa mendefinisikan permasalahan yang diberikan (4)berdiskusi dalam kelompok untuk menyelesaikan permasalahan (5) menentukan aspek-aspek penting dalam memecahkan suatu permasalahan (penulisan karya ilmiah). Hal ini sejalan dengan pendapat Mujianto et al., (2017) yakni secara garis besar prosedur penerapan strategi PBL mencakup (a) siswa diberi permasalahan yang nyata, (b) siswa mengklarifikasi kasus permasalahan yang diberikan; (c) mendefinisikan masalah; (d) melakukan tukar pikiran berdasarkan pengetahuan yang mereka miliki; (e) menetapkan hal-hal yang diperlukan untuk menyelesaikan masalah. Di samping itu dalam proses penyusunan karya ilmiah meliputi bagian pembuka, bagian inti, dan notasi ilmiah merupakan komponen penting dalam penulisan karya ilmiah. Bagian pembuka terdiri atas kulit luar, halaman judul, prakata, abstrak, daftar isi, daftar lampiran (jika ada). Bagian inti karangan ilmiah terdiri atas pendahuluan, kajian pustaka, metode, analisis dan pembahasan, simpulan dan saran. Notasi ilmiah terdiri atas referensi. 


\section{Simpulan}

Berdasarkan paparan hasil penelitian yang dilakukan dapat disimpulkan bahwa kemampuan menulis karya ilmiah mahasiswa Administrasi Bisnis di Politeknik Informatika Nasional dapat ditingkatkan melalui metode kolaboratif dan PBL. Pada pratindakan rata-rata mahasiswa memperoleh nilai rata-rata 9 dari skor maksimal 20 dengan persentase 44\% untuk aspek bagian awal, 51\% untuk aspek bagian isi, 44\% untuk aspek notasi dan 44\% untuk aspek mekanisme penulisan. Setelah diberikan metode kolaboratif dan problem based learning pada siklus 1, terjadi peningkatan yakni memeroleh nilai rata-rata 12 dengan persentase 61\% untuk aspek bagian awal, 74\% untuk aspek bagian isi, 63\% bagian notasi ilmiah dan 61\% untuk mekanisme penulisan. Pada siklus ke 2 rata-rata nilai yang diperoleh mahasiswa sebesar 16 dengan persentase $77 \%$ untuk aspek bagian awal, 80\% untuk aspek bagian isi, 85\% bagian notasi ilmiah dan $77 \%$ untuk mekanisme penulisan . 


\section{Daftar Pustaka}

Fatimah, F., \& Kartikasari, R. D. (2018). Strategi Belajar Dan Pembelajaran Dalam Meningkatkan Keterampilan Bahasa. Pena Literasi, 1(2), 108. https://doi.org/10.24853/pl.1.2.108-113

Kusmana, S., Kuntarto, E., Boeriswati, E., \& Suhartono. (2019). Cerdas Berbahasa (Y. Mulyadi \& A. Andriyani (eds.); 1st ed.). YRAMA WIDYA.

Mujianto, M., Zubaidi, Z., \& Suprapto YM, Y. (2017). Peningkatan kemampuan menulis karya ilmiah mahasiswa program jaringan telekomunikasi digital ( JTD ) melalui problem based learning. Prosiding Seminar Nasional \#3: Bahasa Dan Sastra Indonesia Dalam Konteks Global, 177-186. https://jurnal.unej.ac.id/index.php/fkipepro/article/view/4868

Musaljon, M., Rafli, Z., \& Attas, S. G. (2019). Peningkatan Keterampilan Menulis Karya Ilmiah Melalui Model Pembelajaran Workshop dan Kolaborasi (Penelitian Tindakan di Program Studi PBSI STKIP Muhammadiyah Bogor). Semnasfip, 32-39. https://jurnal.umj.ac.id/index.php/SEMNASFIP/index

Sriyanti. (2017). PENINGKATAN KEMAMPUAN MENULIS SURAT PRIBADI DENGAN MENGGUNAKAN METODE KOLABORASI ( Penelitian Tindakan Kelas VII MTsN 15 Ciamis ) Program Studi Pendidikan Bahasa dan Sastra Indonesia. Jurnal Diksatrasia, 1(20), 157.

Sudjana, N. (2017). Penilaian Hasil Proses Belajar Mengajar (21st ed.). ROSDA.

Suryani, N., \& Agung, L. (2012). Strategi Belajar Mengajar (A. Pratama (ed.)). Ombak.

Tanjung, H. S., \& Nababan, S. A. (2018). Pengembangan Perangkat Pembelajaran Matematika Berorientasi Model Pembelajaran Berbasis Masalah (PBM) Untuk Meningkatkan Kemampuan Berpikir Kritis Siswa Sma Se-Kuala Nagan Raya Aceh. Genta Mulia, 9(2), 56-70.

Trianto. (2011). Model Pembelajaran Terpadu: konsep, strategi, dan implementasi dalam Kurikulum Tingkat Satuan Pendidikan (KTSP). Bumi Aksara.

Wulandari, B., \& Surjono, H. D. (2013). Pengaruh problem-based learning terhadap hasil belajar ditinjau dari motivasi belajar PLC di SMK. Jurnal Pendidikan Vokasi, 3(2), 178-191. https://doi.org/10.21831/jpv.v3i2.1600 